\title{
JUURNAL.RU
}

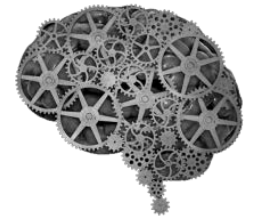

COMPANY GROUP "INTELLEKT"

\author{
Умерова 3.К. \\ ГБОУВО "Крымский инженерно-педагогический университет" \\ Симферополь, Россия
}

doi: 10.18411/lj2016-5-5-06

\section{Изучение внутренний формы слова как метод семантико-когнитивного исследования}

Внутренняя форма слова - признак, в основе наименования предмета, обозначенный при формировании вербальной стороны концепта. Внутренняя форма слова выявляет мотивировочный признак в основе слова в момент его создания. В ходе исторического развития она может затемняться и забываться совсем, в результате появляются слова с утраченной внутренней формой, или немотивированные слова.

Все слова в современном английском языке можно поделить на две группы.

1. Слова с ясной, понятной внутренней формой: saucepan (от «sauce + pan»), hanger (от «hang»).

2. Слова с неясной или непонятной внутренней формой- «mug», «sofa», «pelmet» и т.д. [1, с. 104].

Понятие внутренней формы весьма важно, так как оно имеет под собой вполне определённую психолингвистическую реальность. Дело в том, что представление, что истинным значением слова является его исходное значение, необычайно глубоко укоренено в сознании говорящих.

Часто происхождение слова затемнено, это является следствием ряда факторов. Утрата внутренней формы связана с определенными изменениями в языке: с изменением морфемного строения слова; с изменением фонетического 
облика слова, когда мы не связываем эти слова с данными значениями. Семантическое изменение слова: «tray» - мы не возводим к «tree», «sheet» - к «skirt». Внутренняя форма таких слов теперь утрачена, но она может быть найдена при помощи изучения их этимологии. Утрата внутренней формы может происходить так же по причине того, что слово, послужившее основой номинации, выходит из употребления. В других случаях просто утрачивается связь между производящим и производным словом. Такие связи, однако, присутствуют в языке в латентной форме и могут оживать в поэзии или в языковой игре [2, с. 142].

Внутренняя форма полностью отсутствует у заимствованных слов (связанно это с тем, что даже если заимствованное слово и состоит из значимых частей, то они являются значимыми лишь в том языке, в котором оно создано). Поэтому, непрослеживаемая внутренняя форма может служить указанием на то, что слово заимствованно из другого языка; так, например, можно с уверенностью сказать, что английское слово sofa является заимствованием из арабского suffa, а не наоборот, только потому, что арабское слово имеет внутреннюю форму («ковер»), а русское - не имеет.

Т. Р. Кияк не проводит четких границ между понятиями внутренней формы и лексического значения слова, обозначая, что внутренняя форма простых слов в основном указывает на их лексическое значение. Более того, в знакомом для участников корневом слове внутренняя форма в виде составной части, как признак, как образ, включается в его лексическое значение. В этом можно усматривать определённое преимущество простых слов. Внутренняя форма непроизводных лексических единиц также зависит от следующих внеязыковых факторов: опыт говорящего, его возраст и знания [2, с. 54].

Другой учёный, О. И. Блинов, более полно характеризующий данное отличие, пишет: «Мотивировку слова, даже в тех случаях, когда она совершенно ясна и прозрачна, следует строго отличать от концептуального значения. Мотивировка есть как бы способ изображения данного значения в слове, более 
или менее наглядный образ этого значения, можно сказать - сохраняющийся в слове отпечаток того движения мысли, которое имело место в момент возникновения слова. В мотивировке раскрывается подход мысли человека к данному явлению, каким он был при самом создании слова, и потому мотивировку иногда называют «внутренней формой слова», рассматривая её как звено, через которое содержание, значение слова связывается с его внешней формой - морфологической структурой и звучанием [3, с. 141].

Отсюда следует, что понятие внутренней формы следует отличать от понятия словообразовательного значения, так как последнее является лишь частью первого. Кроме этого, словообразовательное значение может быть свойственно ряду слов с различными формантами, в то время как каждая внутренняя форма рассматривается индивидуально.

Наука, занимающаяся воссозданием потерянной внутренней формы слов, называется этимологией. Изучение внутренней формы слова позволяет исследовать смысловое значение слова, определив особенности национальной концептосферы народа.

\section{Литература:}

1. Арутюнова Н. Д. Язык и мир человека / Н. Д. Арутюнова. - М. : Наука, 1998. -896 c.

2. Кронгауз М. А. Язык. Культура. Познание. / М. А. Кронгауз. - М. : Русские словари, 1997. - 411 с.

3. Блинова О. И. Явление мотивации слов в лексикографическом аспекте / О. И. Блинова // Теория языка и словари. - 1988. - № 2. - С. 137 - 142. 